\title{
Teacher Pedagogic Competency Development Model: A Literature Review
}

\author{
${ }^{1 s t}$ Sri Hartini \\ Universitas Ahmad Dahlan \\ Guidance and Counseling Department \\ Yogyakarta \\ sri.hartini@bk.uad.ac.id
}

\author{
${ }^{3 r d}$ Dody Hartanto \\ Universitas Ahmad Dahlan \\ Guidance and Counseling Department \\ Yogyakarta \\ dody.hartanto@bk.uad.ac.id
}

\author{
${ }^{2 n d}$ Caraka Putra Bhakti \\ Universitas Ahmad Dahlan \\ Guidance and Counseling Department \\ Yogyakarta \\ caraka.pb@bk.uad.ac.id
}

\author{
${ }^{4 t h}$ Muhammad Alfarizqi Nizamuddin Ghiffari \\ Universitas Ahmad Dahlan \\ Guidance and Counseling Department \\ Yogyakarta \\ 1500001138@webmail.uad.ac.id
}

\begin{abstract}
The purpose of this paper is to provide references related to the teacher's pedagogic competency development model. Pedagogic competence is fundamental in education. This is because pedagogic competence is one of the important factors in teaching. Pedagogic competence relates to how a teacher can provide teaching that is not monotonous, fun, creative and meaningful and uses various kinds of media. However, based on several research results, there are still many teachers who have pedagogic competence in the low category. There are still many teachers today who are still teaching using the teacher center method and not the student center, for example, such as the lecture method. On the one hand, the current era can also be said to be an era destructive. This is because technological developments can also threaten existing human resources or teachers. The ability of teachers and teacher quality can be replaced by existing technology. Thus, as a teacher who will face the current era, the need to continue to develop his pedagogical competence. as for the model in developing pedagogic competencies such as field practice activities monitored by supervision, Community-based teacher, mentoring, job-embedded, Online lesson, and so on. Thus, it is expected that with this development the teacher's pedagogical competence can develop optimally so that the quality of education indirectly increases.
\end{abstract}

Keywords - competence, pedagogic, teacher

\section{INTRODUCTION}

Teachers Become a key in the delivery of education. This is because the success of education is shaped by the quality of teachers (Akindutere, 2012). As a profession that is very close to students and a profession that is always there to develop the potential of students, the teacher is deemed necessary to continue to optimize his performance. Quality of students results from quality education. produce quality education, teachers become key success factors (Intan Ahmad, 2016). In addition, the role of the teacher is now increasingly complex, which currently needs to teach in environment multicultural, experts in coordinating students, understanding student needs, the ability to use technology in teaching and so on (Bentri,
2017). The more competent he is, then students will get optimal learning too.

The quality of teaching is not only limited to certification and insight but also related to teaching skills, ability in the application of teaching strategies, selection of creative methods and media for teaching and so on. In connection with the quality of the teaching profession according to Nursalim (2015) said as a profession is not just a job but a special thing that has the characteristics of expertise. In addition, it was clarified by Suhadi (2014) who said that each teacher must fulfil the qualifications and competencies which are the basic capital for the implementation of learning. Thus, a quality teaching profession is a profession that is truly expert and has teaching competencies and good teaching strategies.

This is related to pedagogic competence. Pedagogic competence is a competence which requires teachers to continue to be skilled in the application of existing learning. Based on Mulyasa (Hakim, 2015) said, pedagogic competence is the ability to regulate learning, understanding learning, evaluation and learning development. Teachers who have pedagogical competencies will be able to determine what steps and methods of teaching are most appropriate and give meaning to students (Pantic, 2012). Pedagogic competence and professionalism of a teacher when teaching is the main key in developing quality education (Syahruddin, 2013). Thus, the pedagogic competence must be owned by the teacher at this time.

But in reality, there are still many teachers whose competence is categorized as low. Surapranata (2015) said, if elaborated again, the UKG results for pedagogic competence, the national average is only 48.94, which is below the minimum competency standard (SKM), amounting to 55. Even for this pedagogic, there is only one province whose value above the national average while achieving SKM, 
namely DI Yogyakarta (56.91). In addition, based on the results of research from Bentri (2017), it was stated that based on interviews with several teachers in Indonesia in relation to the 2013 curriculum, most teachers were still in the low category, and this was because teachers did not fully participate in competency development training. These results can conclude that pedagogical competencies need to be continuously developed.

The low pedagogic competence is because there are still many teachers who use teaching methods that are less effective, such as the lecture method. According to Ismail (2008), the method is lecture less effective if used in class with a large number of students, because some of them will less pay attention to the teacher's talk, the teacher is less than optimal in supervising students and talking to themselves with friends. Thus, this pedagogic competence is deemed necessary to optimize teacher teaching abilities.

The phenomenon of the low pedagogic competence of teachers is caused by various things such as lack of insight, lack of experience, or even high salaries can also make the teacher only oriented to the work not the meaning of learning. Teachers who earn income / high pay may be leaving their professionals so that they are less effective in teaching (Harris, 2011). Thus, it is necessary to develop an effective model of teacher pedagogic competence.

\section{LITERATURE REVIEW}

\section{A. Teacher Pedagogical Competenace}

Talking about education, of course, is closely related to the teacher. As a profession that plays an important role in the education process, teachers become one of the determinants of educational success. This is because the teacher is a person who gives students learning and is closest to students when in school. Teachers need to build good relationships or relationships with students, this serves to motivate and manage students' emotions well (Looney, 2011). From here it will be seen, what kind of teacher is needed to teach students.

In connection with what was explained earlier, the focus of the discussion here refers to the quality of the teacher in providing education. Teacher quality is an important key in developing quality education (Harris, 2011). Of course, qualified teachers will be the determinants of existing educational success.

Teacher quality is certainly seen in various aspects. These aspects are the determinants of the quality of teachers today. Looney (2011) explained that qualified teachers need to have several abilities, including having broad knowledge, developing good relationships, classroom management, ability to assess, verbal skills, teaching and collaborative skills at work. Deep by Liakopoulou (2011), that qualified / competent teachers are categorized into four: 1) having good personalities, 2) good teaching skills, 3) extensive knowledge, and 4) teaching attitudes and behaviours. Thus, qualified teachers certainly need to have all of these aspects fulfilled.

Based on the previous explanation, this leads to teacher competence. Teacher competency is a combination of skills, knowledge, attitudes, and values that are reflected in the habits of action and thought (Suhadi, 2014). In addition, according to
Hakim (2015) competence can be said as a person's ability to carry out a task, or work performance or task which is based on various skills, knowledge and work attitudes. From here, competence becomes a series of actions a person takes with a sense of responsibility for the conditions of success in carrying out the task (Yasin, 2011). Competence is one of the determinants of success of the quality of the teacher itself. qualified teachers certainly have good competence.

One of the competencies needed by teachers today is pedagogic competence. Pedagogic competence relates to how teachers teach, teacher teaching skills, use of appropriate strategies and methods. Basically, the concept of pedagogic competence is the ability to be able to understand learners, design an instruction, and implement in learning diagnosis, evaluate learning and develop learning (Hakim, 2015). Clarified by Yasin (2011) Pedagogic competence is the ability of educators to manage students' learning, including; understanding of students, Making learning design, implementing learning, Ability to evaluate learning outcomes, developing students in actualizing their potential.

In addition, pedagogic competence is not only talking about teaching methods, but there are several other things that are more deeply related to pedagogic competence. Pedagogic competence is the ability of individuals to coordinate and the ability to combine sources of knowledge in synergy such as (books, articles and other sources) and combine sources outside of it (such as skills, experience and knowledge) to obtain effective pedagogical abilities (Suciu, 2011). More simply, Apelgren (2010) explains that pedagogic competence is the ability to use attitudes, knowledge, and teaching abilities to help students in the best way. Thus, competence pedagogic is one of the competencies that teachers need to develop at this time.

From here, the quality of pedagogic competencies related to the way teachers teaches students plays an important role in the learning process. Competence in teaching becomes a role in realizing quality learning which is also able to demonstrate the professionalism of the teacher itself (Hakim, 2015). From this, it is very clear that pedagogic competence is a key factor in developing and realizing a high level of quality education (Apelgren, 2011). Therefore, the pedagogic competencies possessed by teachers now need to be developed and optimized.

\section{B. Competency Development Model}

In developing competencies, many competency development models are not only in Indonesia but also in other countries which can be applied in developing competencies. Of course, one model with another model has a different system and form.

There are various types of teacher competency development models. The first model is School-Based Management (SBM). SBM itself is a development which further enhances the effectiveness of the school by giving all the autonomy to school management and stakeholders school in formulating decisions and managing internally (Syahruddin, 2013). Overall the concept of SBM is very simple, what is emphasized is the ability to manage the school itself. 
Conceptually, SBM tends to focus on internal schools. The concept of SBM gives principals, teachers, parents and other educating stakeholders to be given good control in financial matters and school priorities, in a larger context SBM gives control over work resources that are in line with school needs (Syahruddin, 2013). In short, SBM provides openness and gives control over the school system. All can be done through teacher meetings or meetings. From here, the direction and purpose of the school will be determined, as well as optimal school empowerment.

The second model is the lesson study. Lesson study is a teacher's professional development program that was first developed in Japan (Mahmudi, 2009). This development model emphasizes the quality, skills, and experience of existing teachers. lesson study. Here a series of activities are carried out which lead to overall teacher development.

In lesson study, the main target is that teachers have an effort to find effective learning. Lesson study is said to be a process of teacher collaboration with other teachers/teachers, which identifies problems with each teacher, observes learning, evaluates and revises each other's learning so that all activities are carried out progressively and emphasizes research studies or learning research (Mahmudi, 2009). Thus, from these activities, the discovery of new learning methods and strategies which are effective and can be done by teachers who have similar problems.

The third model is the Online Learning Community. The online learning community is a teacher competency development model which is carried out through a series of activities. The online learning community is a floating model that is flexible reflexive and focuses on personal teachers who develop teachers professionally and guide and inspire teachers (Sari, 2012). This online learning community (OLC) is not limited to seeing the quality of the teacher but evaluating what the teacher has done to guide the teacher in the improvement process.

Overall, OLC is more directed towards communities that are conducted online to direct the improvement of the learning process. Members of the OLC themselves direct one another to the context of the teacher itself and its learning and obstacles to the development of the teacher's own competence (Sari, 2012). From here, the process of discussion and direction of the teacher is more to the development of the teacher itself.

The components of this model are 4 things. The components of OLC consist of the community (teacher participation), learning (knowledge development), network (social relations), and technology (which leads to online learning and face-to-face meetings) (Sari, 2012). It's the elements-element an important in the implementation of the OLC.

The fourth model is a scaffolding model. The model scaffolding is a fairly simple teacher competency development program which emphasizes three aspects of diagnosis, responsiveness and release (Smit, 2013). Diagnosis here is more to what is the strengths and weaknesses of teaching, then responsive emphasizes on communicating what needs to be done to professionals to develop thoughts and learning done before, after that handover is done to make space for teachers to develop (Rahman, 2015). Thus, as a whole, this model is considered quite simple in developing teacher quality in the context of the teaching process, teaching ability and developing teacher competencies.

And the last model is Teacher Quality Improvement (TQI). This model is designed to develop teacher competencies in class so that when teachers teach it becomes more interesting and enjoyable for students. here the program is carried out consistently in providing teacher training and mentoring using competency modules (personal, social and pedagogic) which mama aims so that teachers can implement new approaches that make students more interested in learning (Ramdhani, 2012). Here, the teacher's ability to understand new approaches and new insights is the main focus of the TQI development model.

For the pedagogic field, pedagogic modules contain what students need, the methods students need to the media. This program is carried out for two weeks, in a week the teacher focuses on the pedagogical module which in the module, the teacher is asked to understand the psychological child, find the best way to teach, and develop existing learning media (Ramadhani, 2012). Thus, intensively, the practice of the pedagogic competency module will require teachers to be more innovative in finding the most effective way of teaching according to the needs of students.

Thus, these development models competency can be applied and designed to adapt to the school. Each model has its own advantages. However, each model is able to develop competencies teacher more optimally.

\section{METHOD}

Writing method is a literature study (review). Data/information is obtained from various literature and compiled based on the results of the study of data/information obtained. The literature used includes books, legislation, seminar papers, proceedings, journals scientific print editions of and online editions, research results and scientific articles sourced from the internet. The types of data obtained are varied, qualitative and quantitative. The collected data is selected and sorted according to the study topic. Then the preparation of the paper is based on data that has been prepared logically and systematically. Data analysis techniques are descriptive argumentative. Writing is done by looking at the relevance and synchronization between one data/information one with other data/information in accordance with the topics studied. Then, the conclusion of the paper is made. Conclusions are obtained after referring back to the formulation of the problem, the purpose of writing, and the discussion. The conclusions drawn represent the subject matter of the paper and are supported by practical suggestions as for further recommendations.

\section{DISCUSSION}

A. Teacher's Pedagogic Competency Development Model

competence certainly has aspects that need to be owned by the teacher today. Thus, the development model can be adjusted and designed in such a way as to develop optimal 
pedagogical competencies. Of course, there are various kinds of competency development models that can be done to develop a teacher's pedagogical competencies.

\begin{tabular}{|c|c|}
\hline $\begin{array}{l}\text { Pedagogic Competency } \\
\text { Development Model }\end{array}$ & Description \\
\hline School-Based Management (SBM) & $\begin{array}{l}\text { gives principals, teachers, } \\
\text { parents and other educating } \\
\text { stakeholders to be given } \\
\text { control over the recruitment of } \\
\text { competent teachers. Then also } \\
\text { authorizes the development of } \\
\text { supporting facilities for } \\
\text { pedagogic competencies } \\
\text { (media, training, etc.) }\end{array}$ \\
\hline Lesson Study & $\begin{array}{l}\text { Conduct a collaborative } \\
\text { process with other teachers } \\
\text { which aims to observe, } \\
\text { evaluate and discuss each } \\
\text { other related to the way of } \\
\text { teaching. From here, the } \\
\text { teacher will conduct periodic } \\
\text { monitoring as an effort to } \\
\text { optimize } \\
\text { competence. }\end{array}$ \\
\hline Online Learning Community & $\begin{array}{l}\text { Online community, which } \\
\text { contains discussion and } \\
\text { sharing as well as directions } \\
\text { from each member related to } \\
\text { the learning process, teaching } \\
\text { methods, teaching methods, } \\
\text { teaching strategies and } \\
\text { teaching media. The } \\
\text { discussion was conducted } \\
\text { online }\end{array}$ \\
\hline ScaffoldingModel & $\begin{array}{l}\text { three main points, diagnosis, } \\
\text { responsiveness and handover. } \\
\text { Diagnosis: diagnose student } \\
\text { needs, learning barriers, things } \\
\text { that need to be developed from } \\
\text { teaching methods. } \\
\text { Responsive: evaluate what is } \\
\text { lacking, what needs to be } \\
\text { improved and what needs to be } \\
\text { changed from the existing } \\
\text { learning method. } \\
\text { Handover: allows the teacher } \\
\text { to do what has been evaluated } \\
\text { and what has been improved } \\
\text { for his development. }\end{array}$ \\
\hline $\begin{array}{l}\text { Teacher Quality Improvement } \\
\text { (TQI) }\end{array}$ & $\begin{array}{l}\text { Conduct training programs } \\
\text { which use a pedagogic module } \\
\text { for one week. Here what is } \\
\text { trained is the students' } \\
\text { psychological understanding, } \\
\text { teacher's teaching skills, } \\
\text { teaching skills, teacher's } \\
\text { insights, and the latest } \\
\text { approaches to teaching. }\end{array}$ \\
\hline
\end{tabular}

V. COUNCLUSION
Pedagogic competence is a major factor in developing teacher quality. In order to realize effective and optimal education, the teacher needs to continue to optimize his pedagogical competence. This pedagogic competence can be developed through various competency development models, for example, there are SBM, Lesson Study and so on.

Each pedagogic competency development model has its own advantages, so that of the various types of models which are perceived to be suitable for school needs, the school system and effective use. Thus, from these various models, can be a reference for the development of pedagogic competencies. It is expected that the model applied in schools will be able to develop teachers' pedagogical competencies optimally.

\section{References}

[1] Akindutire, I O dan Ekundayo, "Teacher Education in a Democratic Nigeria: Challenges and the Way forward," EducationalResearch,Vol.3, pp. 429-435. 2012

[2] Intan, Ahmad, "Arah \& Kebijakan Kementerian Riset, Teknologi, dan Pendidikan Tinggi: Kurikulum dan Sistem Pembelajaran LPTK," Makalah Disampaikan di Konferensi Nasional Pendidikan(KONASPI) ke VIII, Universitas Negeri, 2016

[3] Bentri, Alwen, "Mastery of primary school teacher pedagogy competency in curriculum 2013 implementation in Indonesia," The International Journal of Counseling and Education, Vol.2, 2017

[4] Nursalim, Mochammad, Pengembangan Profesi Bimbingan \& Konseling, Jakarta: Erlangga, 2015

[5] Suhadi , Edi et. al. "Pengembangan Motivasi Dan Kompetensi Guru Dalam Peningkatan Mutu Pembelajaran Di Madrasah," Ta'dibuna Jurnal Pendidikan Islam, Vol. 3, April 2014

[6] Hakim, Adnan. "Contribution of Competence Teacher (Pedagogical, Personality, Professional Competence and Social) On the Performance of Learning, The International Journal Of Engineering And Science (IJES), Vol.4, pp.01-12, 2015.

[7] Pantic, Natasa dan Theo Wubbles, "Competence-based teacher education: A change from Didaktik to Curriculum culture?," Journal of Curriculum Studies, Vol.44, pp.6187,2012

[8] Syahruddin, Andi Ernawati, Muh. Nasir Ede, et.al. "Teachers' Pedagogical Competence in School-Based Management," Journal of Education and Learning, Vol.7, pp. 213-218, 2013

[9] Surapranata, Sumarna, Pedoman Pelaksanaan Uji Kompetensi Guru, Jakarta:Kemenrisetdikti, 2015

[10] Ismail, SM, Strategi Pembelajaran Agama Islam Berbasis, 2008

[11] Harris, Douglas N. \& Tim R. Sass, "Teacher traning, Teacher Quality, and student achievement," Journal of public economics, Vol. 95, pp.798-812, 2011

[12] Looney, Janet, "Developing High-QualityTeachers: teacher evaluation for improvement," European Journal of Education, Vol.46, pp.440-455, 2011.

[13] Liakopoulou, Maria, "Teachers' Pedagogical Competence as a Prerequisite for Entering the Professionejed," European Journal of Education,Vol. 46, 2011

[14] Yasin, Ahmad Fatah, "Pengembangan Kompetensi Pedagogik Guru Pendidikan Agama Islam di Madrasah (Studi Kasus di MIN Malang I)," Jurnal eL-QUDWAH, Vol.1, April 2011 
[15] Suciu , Andreia Irina, Liliana Mâţă,"Pedagogical Competences - The Key to Efficient Education," International Online Journal of Educational Sciences, Vol.3, pp.411-423, 2011,

[16] Apelgren ,Karin \& Birgitta Giertz, Pedagogical Competence - A Key to Pedagogical Development and Quality in Higher Education: A Swedish perspective on Pedagogical Competence, Swdish: Uppsala University Division for Development of Teaching and Learning, 2010

[17] Mahmudi ,Ali, "Mengembangkan Kompetensi Guru Melalui Lesson Study," Forum Kependidikan, Vol.28, pp.84-89, 2009

[18] Sari, E. R., Teacher professional development in an online learning community : a case study in Indonesia, Edith Cowan University, 2012
[19] Smit, J., Van Eerde, H. a a, \& Bakker, A., "A conceptualisation of whole-class scaffolding," British Educational Research Journal, Vol.39, pp.817-834, 2013

[20] Rahman, B., Abdurrahman, A., Kadaryanto, B., \& Rusminto, N. E, "Teacher-Based Scaffolding as a Teacher Professional Development Program in Indonesia," Australian Journal of Teacher Education, Vol.40, 2015

[21] Ramdhani , Neila, et.al, "Teacher Quality Improvement Program: Empowering teachers to increasing a quality of Indonesian's education,'International Conference on Education and Educational Psychology (ICEEPSY 2012) Procedia - Social and Behavioral Sciences, Vol.69,pp.1836 - 1841, 2012 